\title{
Epidemiology of Occupational Asthma in Tunisia: Results of a First National Study
}

\author{
Maoua Maher ${ }^{1,2 *}$, El Maalel Olfa1,2, Boughattas Wided1,2, Chatti Souhail1,2, \\ Gharbi Ezzeddine3, Kammoun Houda33, Kalboussi Houda1,2, Mlaouah Jabrane3, \\ Abbassi Ammar', Brahem Aicha1,2, Loukil Mouna3, Haj Salah Habib3, \\ Ben Khdimallah Khaled ${ }^{2,4}$, Masmoudi Tasnim ${ }^{2,5}$, Benzarti Mohamed ${ }^{2,6}$, \\ Debbabi Faten1,2, Mrizak Néjib'1,2 \\ ${ }^{1}$ Occupational Medicine and Professional Pathologies Department, Faculty of Medicine of Sousse, Sousse, \\ Tunisia \\ ${ }^{2}$ University of Sousse, Sousse, Tunisia \\ ${ }^{3}$ CNAM Regional Centers of Sousse, Tunis and Sfax, Tunisia \\ ${ }^{4}$ English Department, Faculty of Medicine of Sousse, Sousse, Tunisia \\ ${ }^{5}$ Forensic Medicine Department, Faculty of Medicine of Sousse, Sousse, Tunisia \\ ${ }^{6}$ Department of Pneumology and Allergology, Farhat Hached Teaching Hospital, Sousse, Tunisia \\ Email: *maouamaher@yahoo.fr
}

Received 18 December 2015; accepted 9 May 2016; published 12 May 2016

Copyright (C) 2016 by authors and Scientific Research Publishing Inc.

This work is licensed under the Creative Commons Attribution International License (CC BY). http://creativecommons.org/licenses/by/4.0/

cc) (i) Open Access

\section{Abstract}

Introduction: Apart from its increasingly important frequency, occupational asthma $(\mathrm{OA})$ has become the most important cause of occupational respiratory disorders in developed countries. The number of etiological agents continues to grow following the constant introduction of new harmful substances in industry. Objectives: Determine the prevalence and incidence of $O A$ in our country, the socio-occupational characteristics of asthmatics, and study the forensic and social impact of such pathology. Material and Methods: An exhaustive retrospective epidemiological study was conducted in Tunisia about charts of occupational asthma cases recognized by the competent commissions of the National Medical Care Fund (CNAM) during the period ranging from January $1^{\text {st }}$ 2000 to December $31^{\text {st }}$ 2008. Results: 361 occupational asthma cases, accounting for a prevalence of $7.17 \%$ of all occupational diseases, were recognized during the period of the study. Occupational asthma annual incidence was estimated to be 24.42 cases per 1000000 workers. Our study population was mainly women with a sex ratio of 0.86 . More than a half $(57.6 \%)$ of recognized $0 A$ cases were working in the textile industry sector. Concerning the asthmatics' professional career, most of recognized $0 A$ cases $(n=225$ i.e. $70.6 \%$ of cases $)$ kept their jobs, whereas 58 patients did not. The professional career was linked to gender with a job loss that is 1.79 time more important in asthmatic women. Conclusion: The incidence of occupational asthma in Tunisia is comparable

${ }^{*}$ Corresponding author. 
with that found in other Mediterranean countries. A rigorous and adequate prevention is necessary and allows reducing the importance of this occupational pathology and its serious consequences.

\title{
Keywords
}

\author{
Epidemiology, Occupational Asthma, Pneumology, Allergology, Tunisia
}

\section{Introduction}

Although the influence of the working environment on the outbreak of asthma has been known for a long time and described by Ramazzini at the beginning of the $18^{\text {th }}$ century, researchers' growing interest in occupational asthma (OA) was launched by Jack Pepys who described its many etiologies between 1960 and 1980 [1].

Occupational asthma is a disease characterized by variable airflow limitation and/or hyperresponsiveness and/ or inflammation due to causes and conditions attributable to a particular occupational environment and not to stimuli encountered outside the workplace. Two types of occupational asthma are distinguished based on their appearance after a latency period or not: The classical occupational asthma requiring a period of sensitization and irritant-induced asthma occurring after acute exposure to high concentrations of irritants [2].

High-molecular-weight agents are a major cause of allergic occupational asthma in the workplace. High-molecular-weight agents comprise proteins from plant, microorganism or animal origin in the 10 - $60 \mathrm{kDa}$ range. A few occupational asthma allergens are man-made chemicals such as isocyanates or acid anhydrides. Allergens with a major public health relevance are derived from flour, latex, enzymes and laboratory animals. The structures of antigenic determinants and mechanisms of many occupational allergens have been elucidated, whereas those of others, e.g. of platinum, recognized by immunocompetent cells are still obscure.

The underlying immune mechanisms of allergic occupational asthma correspond to type I allergy, i.e., antigen recognition and processing by antigen-presenting cells, induction of the Th2 immune response resulting in the production of antigen-specific IgE antibodies, and finally release and generation of bronchospastic and inflammatory mediators by mast and other cells [3].

The socio-professional consequences of OA are serious especially as it affects active and often young subjects, and persists in a considerable number of cases, even after cessation of exposure to the risk [4].

Studies carried out in Tunisia on this topic are about isolated cases and limited to a professional group or to a determined exposure. To our knowledge, no study estimated the prevalence and incidence of OA on a national scale. Nonetheless, we conducted this national epidemiological investigation on the whole cases of recognized $\mathrm{OA}$ in order to determine the prevalence and incidence of OA in our country, the asthmatics' socio-professional characteristics, and to study the forensic and social impacts of this pathology.

\section{Material and Methods}

During our investigation, we collected all the files of patients working in the private sector, and known by CNAM as OA carriers during the period ranging from January $1^{\text {st }} 2000$ to December $31^{\text {st }} 2008$.

In the private sector, the recognition of occupational diseases is performed by the medical boards that meet at the head office of the National Medical Care Fund (CNAM) in the cities of Tunis, Sousse and Sfax. The committees are made up of three CNAM doctors, one engineer, and one or several experts in different specialties according to the nature of the conditions to treat.

Our cases are the socially insured presenting an OA recognized by these committees on the basis of some administrative, technical and medical conditions. In order to meet the conditions of forensic recognition, clinically diagnosed asthma should be:

- Mentioned in one of the tables of occupational diseases provided for by the 94 - 28 law of February $21^{\text {st }}$ 1994 [5].

- Confirmed by test or pulmonary function test and recurring after a new exposure to the suspected causal agent.

- Declared before the expiry date of cost management. 
- Occurred in a worker usually exposed to the causal agents.

The usual exposure to the risk is proved by the technical investigation carried out by the CNAM's engineers.

Data collection was done with the help of a pre-established synoptic form. Data sources were medical documents (initial medical certificate, pulmonary function test results, different extra examinations) and administrative ones (occupational disease tax form, employment certificate, income inquiry, an investigation report, results of experts' opinions, medical board's answer, charge sheets), which makes up the patients' files. Our study gain the consent from ethic committee and from the National Medical Care Fund representing patients.

A uni and multivariate, analytic and descriptive statistic analysis was carried out. The inclusion of independent variables in the regression models was done when their degree of significance was less than 0.2. Regarding statistic tests, the signification threshold $\mathrm{p}$ was fixed at 0.05 .

\section{Results}

In all, 361 occupational asthma cases recognized by CNAM during the study period were brought together, representing a prevalence of $7.17 \%$ of all occupational diseases, and $44.19 \%$ of occupational respiratory disorders recognized during this same period. Taking into account the number of active workers affiliated to the National Social Security Fund (CNSS) between 2000 and 2008, the annual incidence of occupational asthma is estimated to be 24.42 cases per 1000000 private sector workers in Tunisia between 2000 and 2008 .

Table 1 shows the distribution of occupational diseases, occupational respiratory disorders, and occupational asthma in terms of years. We notice the progressive increase of the number of cases of recognized occupational asthma with a maximum in the course of the year 2008 (19.4\%).

Occupational asthma was more frequent in the governorates of Monastir (112 cases i.e. 31\%), Sousse (101 cases i.e. 28\%), Sfax (42 cases i.e. 11.6\%) and Ben Arous (25 cases i.e. 6.9\%). No case was declared in five out of the 24 governorates of Tunisia, namely, Kef, Seliana, Beja, Gafsa, and Kebili.

A slight predominance of women was noticed with 194 women (53.7\%) versus 167 men (46.3\%). The sex ratio was of 0.86 . The average age was of $40.63 \pm 8.24$ years with extremes of 21 and 59 years and a median of 41 years. Most of the workers had an average age between 35 and 45 years old.

More than a half (57.6\%) of the cases of recognized OA were working in the textile industry. Those working in the food and timber industries represented respectively $11.9 \%$ and $7.8 \%$ of the whole cases (Table 2).

Most of OA cases ( $\mathrm{n}=256$ i.e. $70.9 \%$ of cases) were secondary to high molecular weight allergens.

Vegetable textile dusts represented the etiologic agent most implicated in the recognized cases of occupational asthma during the study period (200 cases i.e. 55.4\%). Organic isocyanates, cereals and flour represented each $10.2 \%$ of the cases, while wood and cork represented $5 \%$ of the etiologic agents (Table 3 ).

Average seniority of workers in their jobs was $14.84 \pm 8.61$ years with extremes of 1 to 42 years and a median of 13 years. Most of the workers $(n=144$ i.e. $39.9 \%)$ were little skilled, while 129 patients $(35.7 \%)$ were not skilled, and only 88 cases (24.4\%) were skilled.

Table 1. Annual distribution of occupational diseases, occupational respiratory disorders and occupational asthmas.

\begin{tabular}{|c|c|c|c|c|}
\hline \multirow{2}{*}{ Year } & \multirow{2}{*}{$\begin{array}{c}\text { Number of occupational } \\
\text { diseases }\end{array}$} & \multirow{2}{*}{$\begin{array}{l}\text { Number of cases of occupational } \\
\text { respiratory disorders }\end{array}$} & \multicolumn{2}{|c|}{ Number of occupational asthma cases } \\
\hline & & & Number & $\%$ of total \\
\hline 2000 & 326 & 49 & 16 & $4.9 \%$ \\
\hline 2001 & 432 & 61 & 13 & $3 \%$ \\
\hline 2002 & 420 & 65 & 14 & $3.3 \%$ \\
\hline 2003 & 483 & 69 & 45 & $9.3 \%$ \\
\hline 2004 & 597 & 79 & 42 & $13.2 \%$ \\
\hline 2005 & 634 & 121 & 53 & $8.3 \%$ \\
\hline 2006 & 690 & 132 & 53 & $7.7 \%$ \\
\hline 2007 & 755 & 133 & 55 & $7.3 \%$ \\
\hline 2008 & 701 & 108 & 70 & $10 \%$ \\
\hline Total & 5038 & 817 & 361 & $7.17 \%$ \\
\hline
\end{tabular}


Table 2. Distribution of recognized OA cases according to work sector.

\begin{tabular}{ccc}
\hline Work sector & Number & Percentage (\%) \\
\hline Textile industry & 208 & 57.6 \\
Food industry & 43 & 11.9 \\
Timber industry & 28 & 7.8 \\
Automotive and mechanical industry & 15 & 4.2 \\
Metallurgy & 14 & 3.9 \\
Plastic industry & 12 & 3.3 \\
Chemical industry & 7 & 1.9 \\
Ceramics industry & 5 & 1.4 \\
Health sector & 5 & 1.4 \\
Rubber industry & 4 & 1.1 \\
Printing industry & 4 & 1.1 \\
Leather and footwear industries & 4 & 1.1 \\
Electronic industry & 4 & 1.1 \\
Hotel business & 3 & 0.8 \\
Breeding & 3 & 0.8 \\
Toilet paper industry & 1 & 0.3 \\
Tobacco industry & 1 & 0.3 \\
Total & 361 & 100 \\
\hline
\end{tabular}

Table 3. Distribution of recognized OA cases according to the etiologic agent.

\begin{tabular}{|c|c|c|}
\hline Etiologic agent & Number & Percentage (\%) \\
\hline \multicolumn{3}{|c|}{ High molecular-weight agents } \\
\hline Vegetable textile dust & 201 & 55.7 \\
\hline Cereals and flour & 37 & 10.2 \\
\hline Hens duvets & 4 & 1.1 \\
\hline Latex & 4 & 1.1 \\
\hline Enzymes & 4 & 1.1 \\
\hline coffee & 2 & 0.6 \\
\hline Residues of olive oil extraction & 2 & 0.6 \\
\hline Natural felt & 1 & 0.3 \\
\hline Tobacco & 1 & 0.3 \\
\hline \multicolumn{3}{|c|}{ Low molecular-weight agents } \\
\hline Organic Isocyanates & 37 & 10.2 \\
\hline Wood and cork & 18 & 5.0 \\
\hline Acrylic resins & 6 & 1.7 \\
\hline Formaldehyde & 6 & 1.7 \\
\hline Metal carbides & 5 & 1.4 \\
\hline Cyanoacrylate & 5 & 1.4 \\
\hline Heated rosin & 5 & 1.4 \\
\hline Reactive dyes & 5 & 1.4 \\
\hline Sulfites et bisulfites & 4 & 1.1 \\
\hline Dichromates & 4 & 1.1 \\
\hline Azodicarbonamide & 3 & 0.8 \\
\hline Volatile acid anhydride & 2 & 0.6 \\
\hline Vinyl chloride monomer & 2 & 0.6 \\
\hline Aromatic amine & 2 & 0.6 \\
\hline Aliphatic and alicyclic amines & 1 & 0.3 \\
\hline Total & 361 & 100 \\
\hline
\end{tabular}


The mean time of respiratory complaints onset, corresponding to the delay between the beginning of exposure and the onset of symptoms, was of $12.65 \pm 8.58$ years with extremes of 1 and 42 yearsand a median of 1 year. In addition, the average duration of OA progression before it is reported to CNAM was of $2.23 \pm 2.99$ years with extremes of 1 and 24 years.

An occupational rythmicity of complaints was noticed in $71.5 \%$ of OA cases (i.e. in 258 cases).

Only $6.6 \%$ of cases (i.e. $n=24$ ) were tobacco users. Among the cases of recognized OA, 16 patients (i.e. 4.4\% of cases) presented a family history of atopic disease, while most of the cases $(n=348$ i.e. $96.4 \%)$ did not complain of personal history of allergy. Only 6 patients complained of a history of atopic asthma since childhood.

Concerning allergic pathologies associated with OA, allergic rhinitis was present only in 147 patients (40.7\% of cases) and associated with conjunctivitis in 32 patients (8.9\%).

An obstructive syndrome was noticed in 214 cases i.e. in 59.3\% of patients. The values of forced expiratory volume/second (FEV1) and the vital capacity (VC) could be noticed in 155 OA cases. The mean FEV was of $74.4 \% \pm 20.82 \%$ with extremes of $20 \%$ and $117 \%$, while the mean VC was of $84.93 \% \pm 19.18 \%$ and varying between $33 \%$ and $121 \%$.

The reversibility test was carried out in $28 \%$ of OA studied cases. Itwas positive in 93 patients (25.8\%), i.e. in $92 \%$ of the tests. Applied to 164 patients, a non specific metacholine bronchial provocation test was positive in 154 cases (i.e. in $42.7 \%$ of cases and in $93.9 \%$ of tests). The results of other further examinations are illustrated in Table 4.

Rates of permanent partial disability were attributed to 201 OA cases (i.e. 55.68\%) during the study period. The average of PPD was of $21.66 \% \pm 11.38 \%$ with extremes of $0 \%$ and $70 \%$.

Most of recognized OA cases in the course of the study period ( $n=255$ i.e. $70.6 \%$ of the cases) kept their jobs despite their respiratory pathologies (Figure 1).

We studied the relationships between the professional career and the variables of interest. Only gender had a statistically significant relationship with the professional career after multiple binary logistic regression $(\mathrm{p}=$ 0.05). Women had 1.79 times more risk of job loss than men (IC at 95\% [1 - 3.22]).

Table 4. Results of main additional examinations.

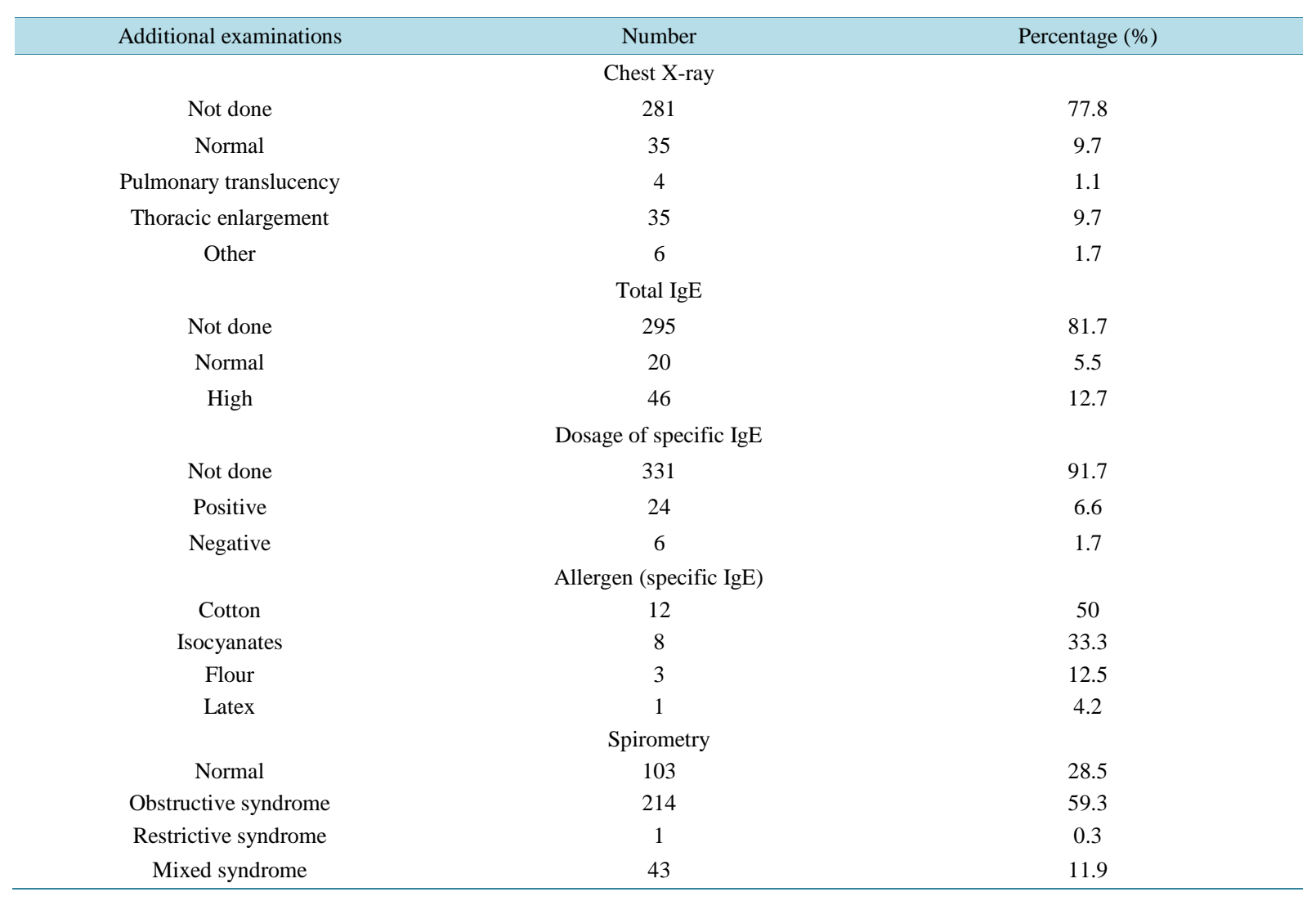




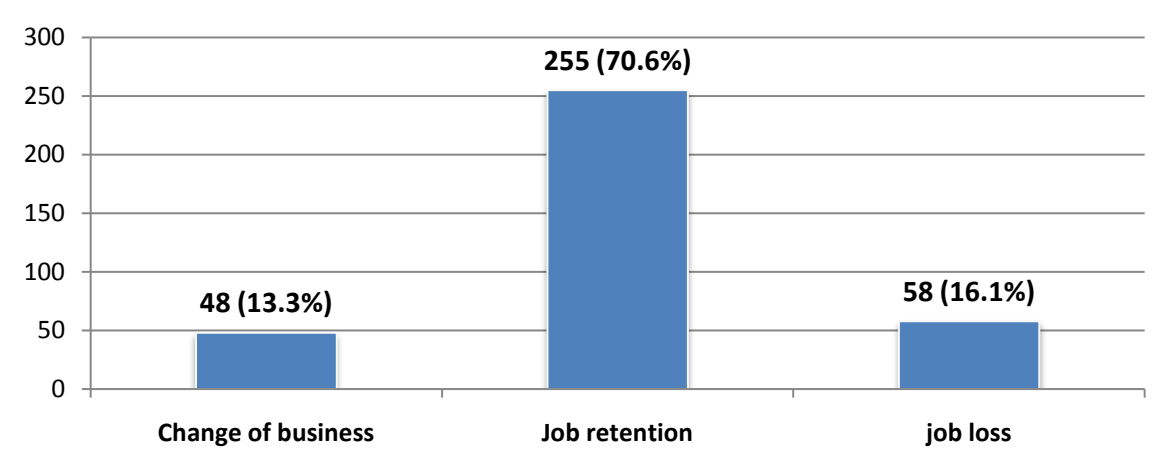

Figure 1. Distribution of recognized OA cases in terms of their professional career.

\section{Discussion}

In the course of our study, some factors could have caused an underestimation of OA in our country. We studied only the cases recognized by the CNAM's committees. Some files of patients with real occupational asthma could have been rejected due to administrative reasons such as: exceeding the deadline of cost managementdefined legally as the delay which separates the end of exposure and the first observation of the disease, or the performance of a profession which is not cited in some tables whose list of works exposing a causal agent is restrictive, or if the causal agent is not listed in any occupational diseases tables provided for by the 94 - 28 law of February $21^{\text {st }} 1994$ regarding compensation for damages resulting from work accidents and occupational diseases in the private sector [5]. Under-reporting can be secondary to misdiagnosis, to ignorance of the laws by the treating doctors or the doctors who made the asthma diagnosis, or to the specificities of the official systems of reporting occupational diseases, which provides only a rough idea about the incidence of occupational asthma in view of the fact that they are based on the patient's voluntary approach in order to get an official recognition for the occupational nature of his/her pathology [6].

Some workers do not report their diseases lest they should lose their job or because the compensation is perceived as low [7]. Moreover, we did not take into consideration the occupational asthmas without latency period. Actually, there are two types of OA: the OA with latency period (immuno-allergic mechanism), and the OA withoutlatency period (non immunologic mechanism) [8]. This second type of asthma comprises two different entities: the Reactive Airways Dysfunction Syndrome (RADS) and the Bronchial Irritation Syndrome [9]. The cases of OA of the type "RADS" are supported in Tunisia under occupational accident in view of their immediate settlement after an unexpected and massive exposure to an irritant agent. The absence of reporting these occupational disease cases could part take in the underestimation of the number of OA cases.

Notwithstanding, our data sources, which were the medical and administrative files of OA cases colligated from the centers of CNAM, enable to meet, in the most possible comprehensive manner, the objective of our study which includes only the cases recognized by the fund.

According to Mapp CE and coll. the forensic data are useful and reliable for the estimation of OA incidence. Added to that, the diagnosis in this type of data source is certain [10].

Most of the studies conducted in Tunisia on occupational asthma express the prevalence of the pathology within a particular sector, or a group exposed to the same etiologic agent. OA accounts for between $9 \%$ and $15 \%$ of asthma cases in adults at the age of professional activity [11]. In their study carried out in Spain on 2646 asthmatics aged between 20 and 44, Kogevinas $M$ and coll. estimated the risk attributable to the occupational origin of asthma to be $6.7 \%$ [12]. In 2010, McHugh MK and coll. carried out study on the prevalence of occupational asthma in the United States between 2001 and 2004 according to the line of business. They found prevalence of: $17 \%$ in miners, $12.5 \%$ in the workers of industries related to health care, $13.1 \%$ in teachers, and $12.6 \%$ in healthcare professionals [13].

Our investigation relates to the cases of occupational asthma recognized by CNAM in the private sector. According to the National Social Security Fund (CNSS), the number of active workers affiliated with this fund increased from 1.307.076 in 2000 to 2.024.671 persons in 2008 [14]. Thus, the annual incidence of occupational asthma isestimated to be 24.42 cases per 1.000 .000 private sector workers in Tunisia between 2000 and 2008 .

Studies carried out by monitoring programs of many countries found annual incidences between 3 and 174 cases per million of workers (Table 5). 
Table 5. Incidence of OA in some countries according to the data of monitoring programs.

\begin{tabular}{lll}
\hline Country & Years & Incidences of OA per million of workers \\
\hline Great Britain: & & \\
- SWORD [6] & $1989-1991$ & 19 \\
- & $1992-1997$ & 38 \\
- SCHIELD [21] & $1991-2005$ & 42 \\
United tates (SENSOR) & & \\
- Michigan [19] & $1988-1994$ & 29 \\
- Massachusetts [19] & $1988-1994$ & 3 \\
Canada [22] & & \\
- British Columbia & 1991 & 92 \\
- Québec (propel) & $1992-1993$ & $42-79$ \\
France (ONAP) [6] [15] & 1997 & 26 \\
Italy, Piedmont (PRIOR) [16] & $1996-1999$ & $24(22-25)$ \\
South Africa (SORDSA) [23] & $1996-1999$ & $24(18-30)$ \\
Australia (SABRE) [24] & $1997-1999$ & 17.5 \\
Finland (FROD) [20] & $1997-2001$ & $31(27-38)$ \\
Belgium [17] & $1986-2002$ & 174 \\
South Korea [18] & $2000-2002$ & $23.5(19-29)$ \\
Tunisia (our study) & $1992-2006$ & 1.6 \\
\hline
\end{tabular}

The investigations whose annual incidences are closer to ours are those of the "Observatoire National des Asthmes Professionnels" (ONAP) in France [15], the PRiOR study conducted in the region of Piedmont in Italy [16], and the study of Vandenplas carried out in 2005 in Belgium [17]. We also notice the big variability of incidences related to very low annual incidences such as that in South Korea (1.6 per million workers) [18], or that in Massachusetts in the united states estimated by the Sentinel Event Notification System for Occupational Risks (SENSOR) to be 3 cases per million workers [19], versus a very high incidence in Finland estimated to be 174 cases per million workers [20]. Different factors can explain such variability. According to KopferschmittKubler MC, it may be: underdiagnosis of the asthmatic disease according to the criteria which were used, work-related underreporting either with the patient or the doctor, varying exposures according to the implicated industries and the asthma generating professions, and ultimately type of the system of declaration (founded on a voluntary approach of the patient) or of reporting (doctors' voluntary reporting) [6]. The system is different in Finland where the declaration/reporting is compulsory (since 1974) and must be made directly at the insurer agency by any doctor who diagnosed an occupational disease [6] and who is not under obligation to issue an initial medical certificate to the patient who decides the declaration as it is the case in Tunisia [5]. Such obligation enables to limit to the maximum the underestimation of OA incidence; the incidence which seems high in Finland is therefore the most accurate.

Contrary to other occupational respiratory disorders, workers with OA tend to be young [1].

The nature of industries established in every region largely determines the distribution of workers in accordance with gender. Thus, women's predominance in our series is partly explained by the importance of the clothing and textile sector in Tunisia mainly in the centre of the country insofar as the governorates of Sousse and Monastir host 39\% of enterprises of this sector. The textile and clothing industries employ more than 200000 persons i.e. $41 \%$ of the total workforce of industries. This sector preferentially hires female, young and little skilled workforce. Similarly, the distribution of workers as men/women with OA was of $47.6 \%$ versus 52.4\% over the period 2001-2002 in Alsace. In this region in France, the distribution of women within the professional sectors brings about a greater women's representation in some fields; it is 3 times higher in the healthcare sector, and almost 40 times higher in the domestic sectors. Healthcare professions are ranked second in OA diagnosed in Alsace. Domestic cofactors, a particular predisposition notably as regards irritants found in the healthcare sector and cleaning occupations, might be evoked so as to explain such over representation of women 
with regard to occupational asthma in this region [26]. More than the half (57.6\%) of recognized OA cases worked in the textile industry. Those working in the food and timber industries represented respectively $11.9 \%$ and $7.8 \%$ of the whole cases.

The sector of textile and clothing industries is considered strategic for the national economy. It is the main sector of manufacturing industry in terms of exportation, employment and added value [25]. Because of the important payroll and textile dust allergenic potential, it seems therefore logic that it occupies the head list of the sectors causing OA. Furthermore, the preventive measures would be particularly inefficient in the textile industry in Tunisia. Indeed, Debbabi F. and coll. found very high dust levels in a textile company units of spinning $\left(1.44 \mathrm{mg} / \mathrm{m}^{3}\right)$, weaving $\left(1.24 \mathrm{mg} / \mathrm{m}^{3}\right)$ and dyeing $\left(0.88 \mathrm{mg} / \mathrm{m}^{3}\right)$. These figures exceed the norm of 0.2 milligrams of inhalable dust per $\mathrm{m}^{3}$ of air [27]. In France, The United Kingdom and South Africa, the most three frequent etiologic agents were flour, isocyanates and latex [28]. In South Korea, the most frequent agents were isocyanates, reactive dyes, metals, and wood dust [18].

Through a literature review, Mapp CE. listed the substances most frequently implicated in the occurrence of OA with latency period. It related to: diisocyanates, flour, laboratory animals and insects, enzymes, rosin, wood dust, latex, acrylates, and glutaraldehyde [10]. Chlorine, sulfur dioxide, combustion products, and ammonia are the most common causes of OA due to irritants [10].

As in our country, the textile industry sector occupies an important place in Morocco. Laraqui CH. and coll. found a prevalence of $11.2 \%$ of OA among 224 employees exposed to cotton dust [29]. A possible explanation of the weak participation of cotton dusts in the occurrence of OA in many European countries would be the tendency of manufacturers of these sectors to startup their firms in countries called "tax havens" and benefit from offshore status.

In 2005, Poonai N. and coll. reported an asthma course time of 4.9 years in 42 patients with OA before the diagnosis of the occupational etiology. In average, patients had been waiting for 7.4 months before discussing the possible occupational origin of their complaints. According to the patients, the causes of this important period were the ignorance of the role of occupational exposure in the genesis of asthma in $41 \%$ of the cases, and the fear to lose one's job in 37\% of the cases [30]. According to Sauni R. and coll., this duration was of 3.2 years in 150 patients with OA in Finland in 2009 [31].

In our study, allergic rhinitis was present only in 147 patients (i.e. $40.7 \%$ of the cases) and was associated with a conjunctivitis in 32 patients (8.9\%). The association between asthma and allergic rhinitis can reach $80 \%$ of the cases [32]. According to Pallasaho P. and coll., the presence of a rhinoconjunctivitis doubles the risk of asthma occurrence [33].

Table 4 shows that job loss is seen in $25 \%$ to $41 \%$ of patients with OA. We noticed that women lose their jobs in case of OA with a risk multiplied by 1.79 compared with men.

Marabini A. and coll. found a relationship between the young age of asthmatics and job retention despite the respiratory complaints [34]. They concluded that the socio-economic factors are the variables which influence job loss.

According to Ameille J, job loss or change of employer is statistically more important in single persons, workers in small businesses, and in asthmatics applying for compensation [35].

In our study, the higher risk of job loss after the onset of OA in women could be explained by their vulnerability. Another possible explanation is that most women with OA work in the textile sector with a fixed-term contract. The onset of the disease could incite their employers not to renew their contracts.

\section{Conclusions}

Our study is the first one to evaluate the incidence of occupational asthma in our country. Today, OA has become frequent giving cause for concern. It is the main cause of occupational respiratory diseases in Tunisia and in industrialized countries. Its prevalence and the diversity of possible etiologic agents increased greatly over the last two decades with the change of technology and the introduction of new molecules and new manufacturing processes to the market.

The recent acquisitions which renew our clinical physiopathological knowledge of asthma, the growing diversity of etiological factors have their reflection in the medico-social imperatives which concern the occupational health doctor. It goes without saying that the socio-economic aspects of this type of asthma are extremely important whether it is the asthmatic person or the employer. OA, which often affects young adults in apparently good health and with sometimes very important family and financial commitments, may mean a turning point in 
one's life. The complete and early eviction of patients means sometimes job loss and important socio-economic consequences. An adequate strategy of prevention is then necessary to reduce the incidence of OA, and to detect and manage it as soon as possible.

\section{Conflict of Interest}

None.

\section{References}

[1] Malo, J.L. and Chan-Yeung, M. (2001) Occupational Asthma. Journal of Allergy and Clinical Immunology, 108, 317328. http://dx.doi.org/10.1067/mai.2001.116432

[2] Cartier, A. (2010) Definition and Diagnosis of Occupational Asthma. In: Sigsgaard, T. and Heederik, D., Eds., Occupational Asthma, Brkhäuser Basel Switzerland, 71-87. http://dx.doi.org/10.1007/978-3-7643-8556-9_5

[3] Baur, X. (2010) Mechanisms of Allergic Occupational Asthma. In: Sigsgaard, T. and Heederik, D., Eds., Occupational Asthma, Brkhäuser Basel Switzerland, 111-140. http://dx.doi.org/10.1007/978-3-7643-8556-9_8

[4] Chan-Yeung, M. (1995) Assessment of Asthma in the Workplace. ACCP Consensus Statement. American College of Chest Physicians. Chest, 108, 1084-117. http://dx.doi.org/10.1378/chest.108.4.1084

[5] Loi n94-28 du 21 Février 1994 (1994) Portant régime de réparation des préjudices causés par les accidents du travail et des maladies professionnelles. Journal Officiel de la République Tunisienne, n 15 du 22.02.1994, 308-317.

[6] Kopferschmitt-Kubler, M.C., Popin, E., Vervloet, D., Ameille, J. and Pauli, G. (2003) L'observatoire national des asthmes professionnels. The National Occupational Asthma Registry. Revue française d'allergologie et d'immunologie clinique, 43, 6-12. http://dx.doi.org/10.1016/S0335-7457(02)00011-4

[7] Ameille, J, Choudat, D., Dewitte, J.D., et al. (2000) Reconnaissance et réparation des asthmes professionnels. Archives des Maladies Professionnelles, 61, 568-573.

[8] Vandenplas, O. and Malo, J.L. (2003) Definitions and Types of Work-Related Asthma: A Nosological Approach. European Respiratory Journal, 21, 706-712. http://dx.doi.org/10.1183/09031936.03.00113303

[9] Brooks, S.M., Truncale, T. and MacCluskey, J. (2007) Occupational and Environmental Asthma. In: Environmental and Occupational Medicine, Lippincott Williams and Wilkins, Philadelphia.

[10] Mapp, C.E., Boschetto, P., Maestrelli, P. and Fabbri, L.M. (2005) Occupational Asthma. American Journal of Respiratory and Critical Care Medicine, 172, 280-305. http://dx.doi.org/10.1164/rccm.200311-1575SO

[11] Balmes, J., Becklake, M., Blanc, P., Henneberger, P., Kreiss, K., Mapp, C., et al. (2003) American Thoracic Society Statement: Occupational Contribution to the Burden of Airway Disease. American Journal of Respiratory and Critical Care Medicine, 167, 787-797. http://dx.doi.org/10.1164/rccm.167.5.787

[12] Kogevinas, M., Antó, J.M., Soriano, J.B., Tobias, A. and Burney, P. (1996) The Risk of Asthma Attributable to Occupational Exposures. A Population-Based Study in Spain. Spanish Group of the European Asthma Study. American Journal of Respiratory and Critical Care Medicine, 154, 137-143. http://dx.doi.org/10.1164/ajrccm.154.1.8680669

[13] McHugh, M.K., Symanski, E., Pompeii, L.A. and Delclos, G.L. (2010) Prevalence of Asthma by Industry and Occupation in the U.S. Working Population. American Journal of Industrial Medicine, 53, 463-475. http://dx.doi.org/10.1002/ajim.20800

[14] CNSS. Données statistiques. Evolution des assurés sociaux (ensemble des régimes). http://www.cnss.nat.tn/fr/html/template31.asp?id=92

[15] Kopferschmitt-Kubler, M.C., Popin, E., Calastreng-Crinquand, A., Ameille, J., Brochard, P., Perdrix, A., et al. (1999) Occupational Asthma in France (1997): A Report of the ONAP Project. European Respiratory Journal, 14, 66s.

[16] Bena, A., D’Errico, A. and Mirabelli, D. (1999) A System for the Active Surveillance of Occupational Bronchial Asthma: The Results of 2 Years of Activity of the PRiOR Program. La Medicina del Lavoro, 90, 556-571.

[17] Vandenplas, O., Labarnois, A., Bugli, C., Kempeneers, E. and Nemery, B. (2005) Épidémiologie de l'asthme professionnel en Belgique. Revue des Maladies Respiratoires, 22, 421-430. http://dx.doi.org/10.1016/S0761-8425(05)85570-6

[18] Oh, S.S. and Kim, K.S. (2010) Occupational Asthma in Korea. Journal of Korean Medical Science, 25, S20-S25. http://dx.doi.org/10.3346/jkms.2010.25.S.S20

[19] Rosenman, K.D., Reilly, M.J. and Kalinowski, D.J. (1997) A State-Based Surveillance System for Work-Related Asthma. Journal of Occupational \& Environmental Medicine, 39, 415-425. http://dx.doi.org/10.1097/00043764-199705000-00007 
[20] Piipari, R. and Keskinen, H. (2005) Agents Causing Occupational Asthma in Finland in 1986-2002: Cow Epithelium Bypassed by Moulds from Moisture-Damaged Buildings. Clinical \& Experimental Allergy, 35, 1632-1637. http://dx.doi.org/10.1111/j.1365-2222.2005.02386.x

[21] Bakerly, N.D., Moore, V.C., Vellore, A.D., Jakkkola, M.S., Robertson, A.S. and Burge, P.S. (2008) Fifteen-Year Trends in Occupational Asthma: Data from the Shield Surveillance Scheme. Occupational Medicine, 58, 169-174. http://dx.doi.org/10.1093/occmed/kqn007

[22] Provencher, S., Labrèche, F.P. and De Guire, L. (1997) Physician Based Surveillance System for Occupational Respiratory Diseases: The Experience of PROPULSE, Québec, Canada. Occupational and Environmental Medicine, 54, 272-276. http://dx.doi.org/10.1136/oem.54.4.272

[23] Esterhuizen, T.M., Hnizdo, E. and Rees, D. (2001) Occurrence and Causes of Occupational Asthma in South AfricaResults from SORDSA’s Occupational Asthma Registry, 1997-1999. South African Medical Journal, 91, 509-513.

[24] Elder, D., Abramson, M., Fish, D., Johnson, A., McKenzie, D. and Sim, M. (2004) Surveillance of Australian Workplace Based Respiratory Events (SABRE): Notifications for the First 3.5 Years and Validation of Occupational Asthma Cases. Occupational Medicine, 54, 395-399. http://dx.doi.org/10.1093/occmed/kqh050

[25] Les industries du textile et d'habillement en Tunisie, monographie. Agence de Promotion de l'Industrie et de l'innovation. Ministère de l'industrie et de la technologie. 2010. http://www.tunisieindustrie.nat.tn/fr/download/CEPI/mono_ith.pdf

[26] Popin, E., Kopferschmitt-Kubler, M.C., Gonzalez, M., Brom, M., Flesch, F. and Pauli, G. (2008) L'asthme professionnel en Alsace: quelques particularités régionales: Résultats de l'intensification locale de l'ONAP en 2001-2002. Revue des Maladies Respiratoires, 25, 806-813. http://dx.doi.org/10.1016/S0761-8425(08)74345-6

[27] Debbabi, F., Mrizek, N., Tabka, Z., Chaudat, D., Zebidi, A. and Conso, F. (2001) Pathologie nasale et respiratoire liée à la poussière de coton dans une entreprise textile à Monastir (Tunisie). Archives des Maladies Professionnelles et de Medecine du Travail, 62, 621-625.

[28] Birba, E., Donnay, C. and Pauli, G. (2003) Aspects actuels de l'asthme et de la rhinite professionnelle (d'après les travaux publiés en 2001-2002). Revue Française d'Allergologie et d'Immunologie Clinique, 43, 401-407. http://dx.doi.org/10.1016/S0335-7457(03)00202-8

[29] Laraqui, C.H., Rahhali, A., Laraqui, O., Tripodi, D., Curtes, J.P., Verger, C. and Caubet, A. (2002) Byssinose et asthme professionnels chez les ouvriers exposés aux poussières de coton. Revue Française d'Allergologie et d'Immunologie Clinique, 42, 133-141. http://dx.doi.org/10.1016/S0335-7457(01)00127-7

[30] Poonai, N., van Diepen, S., Bharatha, A., Manduch, M., Deklaj, T. and Tarlo, S.M. (2005) Barriers to Diagnosis of Occupational Asthma in Ontario. Canadian Journal of Public Health, 96, 230-233.

[31] Sauni, R., Kauppi, P., Helaskoski, E., Virtema, P. and Verbeek, J. (2009) Audit of Quality of Diagnostic Procedures for Occupational Asthma. Occupational Medicine, 59, 230-236. http://dx.doi.org/10.1093/occmed/kqn165

[32] Gamlin, L., Ameille, J., Chaudat, D., Pairon, J.C., Peyrethon, C. and Garnier, R. (2001) Rhinites allergiques professionnelles: bilan des données recueillies auprès de quatre consultations de pathologies professionnelles de la région parisienne en 1997 et 1998. Archives des Maladies Professionnelles et de Medecine du Travail, 62, 374-375.

[33] Pallasaho, P., Juusela, M., Lindqvist, A., Sovijärvi, A., Lundbäck, B. and Rönmark, E. (2011) Allergic Rhinoconjunctivitis Doubles the Risk for Incident Asthma-Results from a Population Study in Helsinki, Finland. Respiratory Medicine, 105, 1449-1456. http://dx.doi.org/10.1016/j.rmed.2011.04.013

[34] Marabini, A., Dimich-Ward, H., Kwan, S.Y., Kennedy, S.M., Waxler-Morrison, N. and Chan-Yeung, M. (1993) Clinical and Socioeconomic Features of Subjects with Red Cedar Asthma: A Follow-Up Study. Chest, 104, 821-824. http://dx.doi.org/10.1378/chest.104.3.821

[35] Ameille, J., Pairon, J.C., Bayeux, M.C., Brochard, P., Choudat, D., Conso, F., et al. (1997) Consequences of Occupational Asthma on Employment and Financial Status: A Follow-Up Study. European Respiratory Journal, 10, 55-58. http://dx.doi.org/10.1183/09031936.97.10010055 